\title{
Energy Consumption - Economic Growth Nexus in Vietnam: An ARDL Approach with a Structural Break*
}

\author{
Ha Minh NGUYEN ${ }^{1}$, Bui Hoang NGOC ${ }^{2}$
}

Received: October 21, 2019 Revised: November 01, 2019 Accepted: November 15, 2019

\begin{abstract}
Energy and energy consumption play an important role in strategies for socio-economic development of the country. In 1995, Vietnam officially entered the $500 \mathrm{kV}$ North-South transmission power line exploits, with a full length of 1,487 km. The purpose of this study is to investigate the breakpoint and the transition effect of energy consumption to economic growth in Vietnam during the period of 1980-1994, and 1995-2016. The Autoregressive Distributed Lag (ARDL) approach and the Bounds test are used to test for the presence of cointegration, whereas the Toda and Yamamoto procedure Granger causality test is used for the direction of causality. The result of the Bounds test validates the existence of cointegration among the included variables. The empirical results provide evidence that energy consumption has a positive impact on the economic growth of Vietnam in the long run. The causality test shows that there is bi-directional causality between energy consumption and economic growth, supported feedback hypothesis. There is a breakpoint in 1995 and the contribution of energy consumption in economic growth in the period of 1995-2016 is lower than the stage 1980-1994. This study suggests Government authorities explore new sources of energy to achieve sustainable economic development in the long run.
\end{abstract}

Keywords : Energy Consumption, Electricity Consumption, Economic Growth, Vietnam, ARDL

JEL Classification Code : F43, O13, O47, Q42, Q43

\section{Introduction}

Energy and infrastructure are the pre-conditions for economic growth. Energy production and energy consumption play an important role in the process of development because it impacts both aggregate supply and aggregate demand. Energy is a factor of the production process, and without energy, all of the machines will not be

* This work is funded by Vietnam National Foundation for Science and Technology Development (NAFOSTED) under Grant No. 502.02-2019.321.

1 First Author, Associate Professor, Ho Chi Minh City Open University, Vietnam. [Postal Address: 97 Vo Van Tan Street, Ward 6, District 3, Ho Chi Minh City 700000, Vietnam] Email: ha.nm@ou.edu.vn

2 Corresponding Author, PhD Candidate, Graduate School, Ho Chi Minh City Open University, Vietnam. [Postal Address: 97 Vo Van Tan Street, Ward 6, District 3, Ho Chi Minh City 700000, Vietnam] Email: ngocbh.16ae@ou.edu.vn

(c) Copyright: Korean Distribution Science Association (KODISA)

This is an Open Access article distributed under the terms of the Creative Commons Attribution Non-Commercial License (http://Creativecommons.org/licenses/by-nc/4.0/) which permits unrestricted noncommercial use, distribution, and reproduction in any medium, provided the original work is properly cited. able to operate. In literature, most empirical studies recognize that reliable access to energy is important to growth both in a direct or indirect manner (Stern, 1993; Halicioglu, 2007; Apergis \& Payne, 2010; Tang et al., 2015). According to the International Energy Agency, the demand for the total primary energy of the world will continue increasing (about 1.4\% annually until 2035), which is true for both developed and developing countries. In Vietnam, electricity production is increasing by $13 \%$ per year, but electricity consumption is increasing by $17 \%$ per year. Therefore, many manufacturing sectors will have difficulties, and the level of Vietnam's growth is also negatively affected.

Understanding and analyzing the relationship between energy and growth is important and of high academic and policy interest for three reasons. First, the need to understand this relationship becomes imminent in the light of unpredictable developments with regard to energy prices. Second, in-depth understanding of the energy-growth links is essential for the analysis of the effect of energy cost fluctuations in the growth, their effects and finding new energy. Third, in developed countries such as the United 
State or the European Union, people will not accept the existence of inefficient energy policies that the Government is implementing. Understanding the relationship between energy consumption and economic growth is more meaningful if set in the context of economic integration and global climate change issues have intensified the debate on the implementation of energy conservation policies and switching to clean energy consumption.

As a country based on agricultural development, Vietnam also encountered a shortage of energy output for development. According to Vietnam Electricity Corporation, the demand for electricity consumption in industry sectors accounted for $52 \%$ in 2016, with the rate of growth increased by $17 \%$ per year. Before 1995 , the power shortage took place provinces, adversely affecting the production, business and living life of people. On the date of May 27. 1994, the $500 \mathrm{kV}$ North-South transmission power line was put into operation which made the power output spike. In the period 1990-1992, the level of electricity production growth is 5-6\%, to the stage 1995-1997, the growth of electricity production is up to $18-19 \%$. The level of economic growth in these two periods also indicates a major change. Before 1995, the level of average economic growth was $5.1 \%$. After 1995, the average economic growth rate was up to $9.5 \%$. There are many causes of Vietnam's economic growth, but with the task of supplying enough electricity to maintain production, electricity production and consumption have contributed to Vietnam's economic development.

The rest of the paper is as follows: Section two provides the economic literature review about the relationship between energy consumption and economic growth in various countries. The research model and methodology are described in section three. Empirical results and discussion are given in section four while conclusions and policy implications are shown in the last section.

\section{Literature Review}

It is not to be denied that energy is considered revolutionized in the development. The role of energy in industrial production is enormous. Energy helps to develop most of the economic sectors as traffic, communication, metallurgy... In economic literature, the energy - growth links have been intensively analyzed by a variety of studies, but the empirical evidence more often than not remains controversial and ambiguous. The empirical results are categorized into four main groups. The first group of findings identifies that there is a uni-directional causality running from growth to energy consumption, confirming the so-called conversation hypothesis. That means the development of current economic activities will affect the demand for energy consumption in the future. The second group of empirical studies suggests the existence of bidirectional causality between energy consumption and economic growth, confirming the feedback hypothesis.
These conclusions imply a joint effect between economic growth and energy consumption so that one affects the other in such a way that a decrease (increase) in economic growth decreases (increases) energy consumption levels and vice versa.

The third group of previous studies shows the existence of uni-directional causality running from energy consumption to economic growth. These results confirm what is known as the growth hypothesis. According to the growth hypothesis, economic growth is affected by energy consumption. As an implication, energy is a fundamental factor for any country to achieve a high and stable economic growth rate. Last, the fourth group of empirical studies provides evidence in support of the so-called neutrality hypothesis. According to this hypothesis, there is no causal relationship between economic growth and energy consumption. That means no effect runs from economic growth to energy consumption and vice versa.

The pioneering study of this topic is studied by Kraft and Kraft (1978). By applying a classical Granger (1969) causality test, their conclusion shows that there is a unidirectional causality running from economic growth to electricity consumption in the United State for the period 1947-1974, supported conversation hypothesis. Following the study of Kraft and Kraft (1978); Akarca and Long (1980); Yu and Hwang (1984) found no causality in the case of the United State for the period 1947-1979 with the same methodology. The conversation hypothesis was supported by the study of Abosedra and Baghestani (1989) for the United State; Cheng and Lai (1997) for Taiwan; Cheng (1998) for Japan; Cheng (1999) for India; Aqeel and Butt (2001) for Pakistan; Zamani (2007) for Iran; Lise and Van Montfort (2007) for Turkey; Ang (2008) for Malaysia; Zhang and Cheng (2009) for China; Bartleet and Gounder (2010) for New Zealand. To explain to the conversation hypothesis, the authors indicate to develop economic activities, it is necessary to use machinery. So, an increase in economic activities in the present will increase the demand for energy consumption in the future.

Following the pioneer study of Kraft and Kraft (1978), various studies have investigated the topic of energy-growth links which their findings seem to be mixed and ambiguous. The absence of consensus can be explained by the application of different estimation methods and data collected from developed and developing countries. Tsani (2010) using the Toda and Yamamoto (1995) procedure, the results show that there is a uni-directional causality running from GDP to energy consumption for Greece in the period 1960-2006, respectively. But, with the same methodology, Payne (2009), Soytas and Sari (2009) found no causal relationship between GDP and energy consumption in the United State in the period 1949-2005, for Turkey in the period 1960-2000. In addition, the growth hypothesis found in the study of Paul and Bhattacharya (2004) for India; Lee and Chang (2005, 2007) for Taiwan; Ho and Siu (2007) for Hong Kong; Odhiambo (2009) for Tanzania; Abosedra et al. (2009) for Lebanon; Chang (2010) for China; Alam et al. 
(2012) for Bangladesh; Akadiri et al. (2019) for South Africa... by applying the Vector Error Correction Model.

Moreover, Glasure and Lee (1997); Ghali and El-Sakka (2004); Dagher and Yacoubian (2012) employed Hsiao's Granger causality test for Korea in the period 1961-1990, for Canada in the period 1961-1997, for Lebanon in the period 1980-2009. Their results show the presence of the feedback hypothesis. Authors of feedback hypothesis are often persuaded to suggest the implementation of a dual strategy, which means that economic growth should be associated with the waste of energy consumption. Using clean energy, explore new energy sources and the development of high technology are the best illustrations of effective energy consumption and economic growth. This hypothesis was supported by the study of Hwang and Gum (1991); Oh and Lee (2004); Tang (2009); Ziramba (2009); Belloumi (2009).

Nevertheless, Halicioglu (2009) examined the relationship between GDP and energy consumption in Turkey over the period of 1960-2005 by applying the ARDL model and Granger causality test. The results show the absence of a causal relationship that is consistent with the neutrality hypothesis. Fatai et al. (2004), Payne (2009), Soytas and Sari (2009) employed the Toda and Yamamoto procedure, the authors conclude that there is no causal relationship between GDP and energy consumption in the case of New Zealand, Turkey and United State. To explain the neutrality hypothesis, Apergis and Payne (2009) emphasized the energy-growth links are only significant in developed and developing countries. Because, in underdeveloped countries most of the factors for development, such as capital, infrastructure, education and high technology are limited. Economic activities are based on nature so that the demand for energy consumption is low.

Tang et al. (2015) analyzed the energy-growth links in Vietnam using the neoclassical Solow growth framework from 1971-2011. The results revealed that energy consumption has a positive impact on GDP in the long run. There is a uni-directional causality running from energy consumption to GDP. Long et al. (2018) employed the ARDL model, Toda and Yamamoto procedure over the period of 1990-2015 in Vietnam. They found evidence to conclude that electricity consumption has a positive impact on GDP per capita in both the short-run and long run. The causality test is the same as the conclusion of Tang et al. (2015) supported the growth hypothesis. However, two studies are based on an assumption that the impact of energy consumption on economic growth is the same through periods. There are two reasons to believe that the assumption is not really reasonable. First, the contributions of such factors as capital, labor, energy into economic growth will differ in the period of economic growth and recession. Second, the advancement of high technology helps the machinery consume less energy. The differences in the conclusion of previous studies and whether there exists "structural break" demonstrate the need for new studies about this relation.

\section{Model and Methodology}

\subsection{The Model}

The main goal of this study is to investigate the "structural break" and the impact of energy consumption on economic growth in the case of Vietnam in the period 19801994 and 1995-2016. Because the $500 \mathrm{kV}$ North-South transmission power line has entered since 1995. In the energy-growth literature, the model has been tested broadly in recent years, such as the study of Glasure and Lee (1997), Tang et al. (2015), Binh (2011), Long et al. (2018), Nguyen et al. (2019). We followed these studies to propose the model for this study, as follows:

$$
L n G D P_{t}=\beta_{0}+\beta_{1} L n E C_{t}+\beta_{2} \cdot D T_{t}+\beta_{3} \cdot(E C . D T)_{t}+u_{t}
$$

Data was collected from International Energy Agency (IEA) and United Nations Conference on Trade and Development (UNCTAD) over the period of 1980-2016. LnGDP is the logarithm of GDP per capita (at a fixed price of 2010, unit is US dollar). LnEC is the logarithm of total electricity consumption (unit is Billion $\mathrm{kWh}$ ). "DT" is the dummy variable. If there exists a "structural break" in the data, "DT" will be 0 if data was collected before the "break" point, "DT" will be 1 if data was collected after "structural break". (EC.DT) is interactive variable and (EC.DT) $=\mathrm{DT} *$ LnEC. It represents the volatility of electricity consumption when electricity production increases.

If $\hat{\beta}_{2} \neq 0$ and have significant, that means there exists a "break" point and the impact of energy consumption on economic growth is the difference in two periods. The minimum energy consumption is $\hat{\beta}_{0}$ in the period before the "break" point, is $\left(\beta_{0}+\beta_{2}\right)$ in the period after the "break" point. If $\hat{\beta}_{3}>0$ and have significant, this implies the impact of energy consumption on economic growth in the period after the "break" point is bigger than the effect in the period before the "break" point.

\subsection{Methodology}

Clearly, an estimate of Ea.1 only vields the long-run effects of exogenous variables. In order to analyze the shortrun and the long-run impact of energy consumption, we employed the ARDL approach, proposed by Pesaran et al. (2001). Various econometric approaches have been used for short-run and long-run estimations such as an approach by Engle and Granger (1987), Johansen and Juselius (1990), Johansen (1996). The ARDL approach has some advantages, as follows: First, the estimations are unbiased and even in the case of small sample size; Second, it can apply in all three cases whether the variables are stationary at $\mathrm{I}(0)$ or stationary at $\mathrm{I}(1)$ even there is a mixture of both. Third, if 
cointegration confirms among variables, then it is a useful approach for both short-run and long-run dynamics. Fourth, this is the only approach that provides us with some explicit tests through which we can explore that exclusive cointegration exists or not instead of assuming vector existence. (Nkoro \& Uko, 2016; Rahman et al., 2019). We can rewrite Eq. 1 in the ARDL approach, as follows:

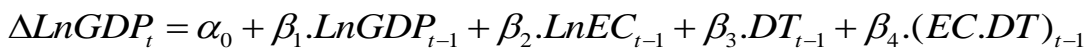

$$
\begin{aligned}
& +\sum_{k=1}^{m 1} \alpha_{1 k} \cdot \Delta L n G D P_{t-k}+\sum_{k=0}^{m 2} \alpha_{2 k} \cdot \Delta L n E C_{t-k}+\sum_{k=0}^{m 3} \alpha_{3 k} \cdot \Delta D T_{t-k}+\sum_{k=0}^{m 4} \alpha_{4 k} \cdot \Delta(E C \cdot D T)_{t-k}+\omega_{t}
\end{aligned}
$$

where: $\Delta$ is first difference

$\beta_{1}, \beta_{2}, \beta_{3}, \beta_{4}$ are coefficients of the long-run impacts $\alpha_{1}, \alpha_{2}, \alpha_{3}, \alpha_{4}$ are coefficients of the short-run impacts $\omega_{\mathrm{t}}$ is the error

First, we estimated Eq.2 based on the Ordinary Least Square (OLS) method. Second, we employed F-test to test the cointegration among variables in the long-run. The null hypothesis $\left(H_{0}: \beta_{1}=\beta_{2}=\beta_{3}=\beta_{4}=0\right)$ indicated that there is no cointegration against the alternative hypothesis $\left(H_{1}: \beta_{1} \neq\right.$ $\beta_{2} \neq \beta_{3} \neq \beta_{4} \neq 0$ ) which indicated that there is cointegration among the variables. According to Pesaran et al. (2001), if F value lies below the $\mathrm{F}$ critical values (the lower bound value, $\mathrm{I}(0))$, it is the indication toward the acceptance of the null hypothesis. That means, there is no cointegration among variables. While the $F$ value exceeds the $F$ critical value (the upper bound value, I(1)), we will reject the null hypothesis.

After confirmation that there exists cointegration among the variables in the long-run, Eq. 2 will be estimated by Error Correction Model (ECM) as follows:

$$
\Delta L n G D P_{t}=\alpha_{0}+\lambda . E C M_{t-1}+\sum_{k=1}^{m 1} \alpha_{1 k} \cdot \Delta L n G D P_{t-k}+\sum_{k=0}^{m 2} \alpha_{2 k} . \Delta L n E C_{t-k}+\sum_{k=0}^{m 3} \alpha_{3 k} . \Delta D T_{t-k}+\sum_{k=0}^{m 4} \alpha_{4 k} . \Delta(E C . D T)_{t-k}+\tau_{t}
$$

Where: $\mathrm{m}_{1}, \mathrm{~m}_{2}, \mathrm{~m}_{3}, \mathrm{~m}_{4}$ are the optimal lag length of the variables calculated by the ARDL model following AIC, SC criteria. In Eq.3, if $\exists \lambda \neq 0$ and have significant which indicated that economic growth can itself adjust to long-run equilibrium after short-run "shocks". In order to test the stability of the short-run and the long-run coefficients, we applied the Cumulative Sum of Recursive Residuals test (CUSUM test) and Cumulative Sum of Square Recursive Residuals test (CUSUMSQ test). In addition, we have to ensure that our model is reliable. We employed a number of diagnostic tests, such as normality distributed, autocorrelation and heteroskedasticity test.

Using the ARDL approach, we can identify the impact of energy consumption on economic growth in the case of Vietnam in the short-run and long-run. But, these results do not guide us about the causal relationship among the variables. In this study, we used the modified Wald test (MWald), proposed by Toda and Yamamoto (1995). The Toda and Yamamoto procedure is based on the Vector Autoregressive model. Using the VAR model, the causal relationship between LnGDP variable and LnEC variable is illustrated as follows:

$$
\begin{aligned}
& \operatorname{LnGDP}_{t}=\alpha_{0}+\sum_{i=1}^{h} \alpha_{1 i} \operatorname{LnGDP}_{t-i}+\sum_{j=h+1}^{p} \alpha_{2 i} \operatorname{LnGDP}_{t-j}+\sum_{i=1}^{h} \delta_{1 i} \operatorname{LnEC}_{t-i}+\sum_{j=h+1}^{p} \delta_{2 i} \operatorname{LnEC}_{t-j}+\mu_{1 t} \\
& \operatorname{LnEC}_{t}=\beta_{0}+\sum_{i=1}^{h} \beta_{1 i} \operatorname{LnEC}_{t-i}+\sum_{j=h+1}^{p} \beta_{2 i} \operatorname{LnEC}_{t-j}++\sum_{i=1}^{h} \alpha_{1 i} \operatorname{LnGDP}_{t-i}+\sum_{j=h+1}^{p} \alpha_{2 i} \operatorname{LnGDP}_{t-j}+\mu_{2 t}
\end{aligned}
$$

Note: $\mathrm{h}$ is the optimal lag order of the VAR model is selected by the AIC critical value. While $\mathrm{p}=\left(\mathrm{h}+\mathrm{d}_{\max }\right)$, with $\mathrm{d}_{\max }$ is the maximum integrated order of series, obtained from the stationarity test of variables. According to Toda and Yamamoto (1995), the maximum of $d_{\max }$ is 2, because if $d_{\max }$ $>2$ the tests based on F-statistic are not reliable (Nkoro \& Uko, 2016; Davoud et al. 2013). In Eq.4, if $\exists \delta_{1, i} \neq 0, \forall i$ this indicated that LnEC variable is causal to LnGDP. In Eq.5, if $\exists \alpha_{1, i} \neq 0, \forall i$ this indicated that LnGDP variable is causal to LnEC. In comparison to the classical Granger test, according to Rambaldi and Doran (1996), Mavrotas and Kelly (2001) the advantages of the Toda and Yamamoto procedure are given, as follows: First, Granger testing can give spurious regressions on functions with time lags on integrated variables. Second, F statistic can be used only when variables are cointegrated. Third, the Toda and Yamamoto test for Granger non-causality is conducted from modified Wald test (MWald) and in Seemingly Unrelated Regression models (SUR models). So that, the Toda and Yamamoto procedure minimizes the risk of determination of each 
variable's optimal lag order and it can be applied to the variable is stationary at $\mathrm{I}(0)$ or at $\mathrm{I}(1)$ or a mixture of both and whether cointegration or no-cointegration.

\section{Empirical Results and Discussion}

\subsection{Descriptive Statistics}

\subsubsection{Overview of the $500 \mathrm{kV}$ North-South} Transmission Power Line

Vietnam's economy has changed rapidly in the past few decades, from an agricultural economy to a modern mixed economy. The GDP per capita has increased nearly 20 times, from USD 114 in 1990 to USD 2,109 in 2015 (at a fixed price of 2010). As a developing country with the advantages of geographic position, Vietnam is in a favorable condition for primary energy resources development such as wind, electricity, gas, hydro, solar and geothermal. But, the energy supply is always lower than consumer demand. This status is continuous and cannot be terminated soon. In 2015, the total primary energy supply of Vietnam was 70,588 KTOE, of which commercial energy accounted for $75.5 \%$ and noncommercial energy accounted for $24.5 \%$. The growth rate of commercial primary energy supply grew by $9.5 \%$ per year. This rate was higher than the GDP growth rate during the same period, leading to the elasticity coefficient of commercial energy to GDP, greater than 1. Among commercial energies, natural gas had the highest growth rate with 13.4\%/year. The growth rate of coal, oil products, and hydropower in the same period was $12.2 \%, 6.2 \%$ and $27.6 \%$ per year, respectively. Vietnam's main drives for energy consumption growth include: Industrial growth, living household, and transportation. In 2016, the industrial sector is still the largest consumer with $43.0 \%$, followed by the residential sector with $29.6 \%$ and the transportation sector with $22,7 \%$.

Economic development in Vietnam has driven strong growth in electricity demand, which reflects rapid industrialization, an expansion of business and services and also rising household consumption in line with rising living standards. According to Vietnam Electricity Corporation, Viet Nam's energy demand increased rapidly between 2001 and 2017 with an estimated average growth of $11.3 \%$ per year. In 2016, the total demand for electricity consumption is 143 billion $\mathrm{kWh}$ and was predicted to continue to grow in the next 15 years.

Since 1995, Vietnam has moved from a position of energy exporter to a net importer. The power supply is insufficient to meet demand. Vietnam faces the prospect of an electricity shortage due to rapid economic growth in the Southern provinces. Thus, Vietnam still needs to import electricity from China and Laos. In May 1995, Vietnam officially entered the $500 \mathrm{kV}$ North-South transmission power line exploits, with a full length of $1,487 \mathrm{~km}$ through 17 cities, provinces from Hoa Binh province to Phu Lam,
Ho Chi Minh city. This helps to solve the local shortage of electricity production in Northern, Central and Southern areas in Vietnam. However, Vietnam's electricity losses are still at a high rate (average of $7.47 \%$ ). In addition, the intensity of Vietnamese power consumption increased rapidly in the period of 2005-2017, while the world's tendency was not changed. In 2005, the power consumption of Vietnam is lower than in China. In 2017, it is roughly doubled compared to China and it is three times higher than the average of the world. In other words, to make 1 unit of income, Vietnam has three times of electricity consumption compared to the average of the world.

\subsubsection{Descriptive Statistics}

Data on the electricity consumption was collected from IEA and data on the economic growth was collected from UNCTAD in the period of 1980-2016. The descriptive statistics of variables is shown in Table 1 .

Table 1: Descriptive Statistic

\begin{tabular}{|l|c|c|c|c|}
\hline Variables & Mean & Maximum & Minimum & Std.Error \\
\hline LnGDP & 6.54 & 7.46 & 5.74 & 0.54 \\
\hline LnEC & 2.92 & 4.96 & 1.19 & 1.27 \\
\hline DT & 0.56 & 1.00 & 0.00 & 0.50 \\
\hline EC.DT & 2.19 & 4.96 & 0.00 & 2.03 \\
\hline
\end{tabular}

\subsection{Empirical Results and Discussion}

\subsubsection{Unit-root Test}

In economic literature, most of the economic variables are non-stationary. In order to avoid the empirical results may be spurious, we apply the unit root test to confirm the level of stationery among involving variables.

Table 2: Stationary Test

\begin{tabular}{|c|c|c|c|c|}
\hline Variables & ADF test & PP test & $\begin{array}{c}\text { Zivot \& Andrew } \\
\text { test }\end{array}$ & $\begin{array}{c}\text { Break } \\
\text { year }\end{array}$ \\
\hline LnGDP & -2.057 & -1.913 & $-6.815^{\star * \star}$ & 1999 \\
\hline$\Delta$ LnGDP & $-2.384^{*}$ & $-2.548^{*}$ & -3.8097 & 1991 \\
\hline LnEC & -2.596 & -2.669 & -4.322 & 2005 \\
\hline$\Delta \mathrm{LnEC}$ & $-3.037^{\star \star}$ & $-2.934^{\star}$ & $-5.015^{\star *}$ & 1995 \\
\hline DT & -1.122 & -1.122 & - & - \\
\hline$\Delta \mathrm{DT}$ & $-5.917^{* *}$ & $-5.917^{* \star *}$ & - & - \\
\hline (EC.DT) & -2.189 & -0.327 & $-15.023^{\star \star \star}$ & 1995 \\
\hline$\Delta$ (EC.DT) & $-5.721^{\star \star \star}$ & $-5.794^{\star * *}$ & $-95.687^{\star \star \star}$ & 1995 \\
\hline
\end{tabular}
$10 \%$.

In this study, following Augmented Dickey and Fuller (1981) (ADF test), Phillips and Perron (1988) (PP test), Zivot and Andrew (2002), we use unit root which includes structural breaks. The stationary test is presented in Table 2 . With the null hypothesis $\left(\mathrm{H}_{0}\right.$ : Data is not stationary) against alternative hypothesis $\left(\mathrm{H}_{1}\right.$ : Data is stationary), the unit root test shows that all of the variables are stationary at first difference with both ADF and PP test. According to the Zivot and Andrew test, there exists a structural break in 1995. This result implies that the conditions to apply the 
ARDL approach, the Toda and Yamamoto test are satisfied. The existence of "structural break" indicates that the impact of energy consumption on economic growth is different in the period before and after the structural break. The test of cointegration among variables should also be checked for this structural break.

\subsubsection{Cointegration Test}

Because all of the variables are stationary at I(1), so we have to check the cointegration among variables in the long run. Recent studies, a new econometric approach known as the Bound test and the ARDL approach proposed by Pesaran et al. (2001). The null hypothesis of no cointegration in Eq.2 is $\left(H_{0}: \beta_{1}=\beta_{2}=\beta_{3}=\beta_{4}=0\right)$ against the alternative hypothesis $\left(H_{1}: \beta_{1} \neq \beta_{2} \neq \beta_{3} \neq \beta_{4} \neq 0\right)$. To confirm cointegration, we follow the critical value of the F statistic given by Pesaran et al. (2001), Narayan (2005). According to them, if $\mathrm{F}$ value lies below the lower bound value, it is the indication toward the acceptance of the null hypothesis, it means there is no cointegration while when $\mathrm{F}$ value exceeds the upper bound value, we will reject null hypothesis the of no cointegration. The cointegration test in Table 3 shows that $\mathrm{F}$ value $=6.199>\mathrm{I}(1)$ critical value $=4.66$ and significant at $1 \%$ level. So, it is statistical evidence to reject the null hypothesis.

Table 3: The Result of Bound Test

\begin{tabular}{|l|c|c|c|c|}
\hline F-Bounds test & \multicolumn{4}{|c|}{ Null hypothesis: No level relationship } \\
\hline Test Statistic & Value & Signif & $\mathbf{I}(\mathbf{0})$ & $\mathbf{I}(\mathbf{1})$ \\
\hline F-statistic & 6.199 & $10 \%$ & 2.37 & 3.2 \\
\hline $\mathrm{k}$ & 3 & $5 \%$ & 2.79 & 3.67 \\
\hline & & $2.5 \%$ & 3.15 & 4.08 \\
\hline & & $1 \%$ & 3.65 & 4.66 \\
\hline
\end{tabular}

The Bound test shows that there exists cointegration among the variables, but it is not interested in structural breaks. To examine the cointegration among variables in which data have a structural break, we employed the Gregory and Hansen (1996) test. Accordingly, the value of the test statistic (-6.37) is lower the critical value (-6.02) and is significance at $1 \%$. This result indicated although there exists a structural break, also there is cointegration among variables in the long run. The Gregory and Hansen test also shows that the break has appeared in 1995. It is time for Vietnam to enter the 500KV North-South transmission power lines to exploit. The Gregory and Hansen test is presented in Table 4.

Table 4: Result of the Gregory and Hansen Test

\begin{tabular}{|c|c|c|c|c|c|c|}
\hline & \multirow{2}{*}{$\begin{array}{c}\text { Test } \\
\text { statistic }\end{array}$} & \multirow{2}{*}{ Breakpoint } & \multirow{2}{*}{ Date } & \multicolumn{3}{|c|}{ Critical value } \\
\cline { 5 - 7 } & & & $\mathbf{1} \%$ & $\mathbf{5} \%$ & $\mathbf{1 0} \%$ \\
\hline ADF & -6.37 & 16 & 1995 & -6.02 & -5.50 & -5.24 \\
\hline
\end{tabular}

\subsubsection{Error Correction Model}

After confirmation of cointegration, we apply the error correction model to determine the impact of energy consumption on economic growth in the short run. The advantage of the ARDL approach is auto-choice the optimal model based on AIC, HC information criterion, and R square. With the data of Vietnam, the optimal ARDL model is $\operatorname{ARDL}(2,4,2,1)$. That means, $\mathrm{m}_{1}$ is $2, \mathrm{~m}_{2}$ is $4, \mathrm{~m}_{3}$ is 2 and $\mathrm{m}_{4}$ is 1 , in Eq.3. The coefficients of the short-run impacts are shown in Table 5.

Table 5: Results of the Error Correction Model

\begin{tabular}{|c|c|c|c|c|}
\hline Variable & Coefficient & Std. Error & t-Statistic & Prob \\
\hline$\Delta$ LnGDP $(-1)$ & 0.6699 & 0.0939 & 7.1279 & 0.0000 \\
\hline$\Delta$ LnEC & -0.0304 & 0.0382 & -0.7972 & 0.4347 \\
\hline$\Delta$ LnEC(-1) & -0.0752 & 0.0447 & -1.6819 & 0.1081 \\
\hline$\Delta$ LnEC(-2) & -0.1808 & 0.0448 & -4.0337 & 0.0007 \\
\hline$\Delta$ LnEC(-3) & -0.1323 & 0.0489 & -2.7031 & 0.0137 \\
\hline$\Delta$ DT & -0.2607 & 0.0988 & -2.6373 & 0.0158 \\
\hline$\Delta$ DT(-1) & 0.0112 & 0.0079 & 1.4078 & 0.1745 \\
\hline$\Delta($ EC.DT) & 0.1059 & 0.0401 & 2.6428 & 0.0156 \\
\hline ECM(-1) ${ }^{*}$ & -0.4435 & 0.0727 & -6.0991 & 0.0000 \\
\hline
\end{tabular}

The coefficient of ECM is $\lambda=-0.4435$ and significant at $1 \%$ level. Thus, it also validates the confirmation of the cointegration among variables. The error correction mechanism advocates that economic growth re-adjust to long-run equilibrium after each short-run "shock" created by energy consumption. Three years is the time needed for an adjustment $(=1 / / \lambda l)$. The result of Table 5 also indicated that energy consumption has a positive impact on economic growth in the short run but not yet significance.

\subsubsection{Diagnostic Test}

The next step is a diagnostic test. We will conduct additional diagnostic tests including: Heteroskedasticity test, autocorrelation test, distribution of residuals, functional test. In order to test the stability of the long-run coefficients and the short-run dynamics, we employed the cumulative sum of recursive residuals (CUSUM) test and the cumulative sum of squares of recursive residuals (CUSUMSQ) test. The diagnostic test is presented in Table 6 and the CUSUM, CUSUMSQ tests are shown in Figure 1a, Figure 1b.

Table 6: Diagnostic Test

\begin{tabular}{|l|c|}
\hline Type of test & Obs ${ }^{*} \mathbf{R} \_$square/F_statistic \\
\hline Heteroskedasticity test (White test) & $13.47($ Prob $=0.336)$ \\
\hline Serial correlation LM test (Breusch \& Godfrey test) & $0.830($ Prob $=0.362)$ \\
\hline Distribution of Residuals (Normality test) & $1.657($ Prob $=0.436)$ \\
\hline Functional test (Ramsey_reset test) & $0.103($ Prob $=0.752)$ \\
\hline
\end{tabular}

The outcome of the four diagnostic tests of Lagrange multiplier, serial correlation, Ramsey's misspecification, Jacque and Bera normality and the autoregressive conditional heteroscedasticity tests show that our model passed all the four diagnostics tests because we cannot reject any hypothesis and this demonstrates the consistency and efficiency of our model. Next, Figure.1a and Figure.1b show that the blue lines for both CUSUM and CUSUMSQ lie within the critical bounds and are significance at $5 \%$. This is statistical evidence to conclude that our model is stable and the estimated results are reliable. 


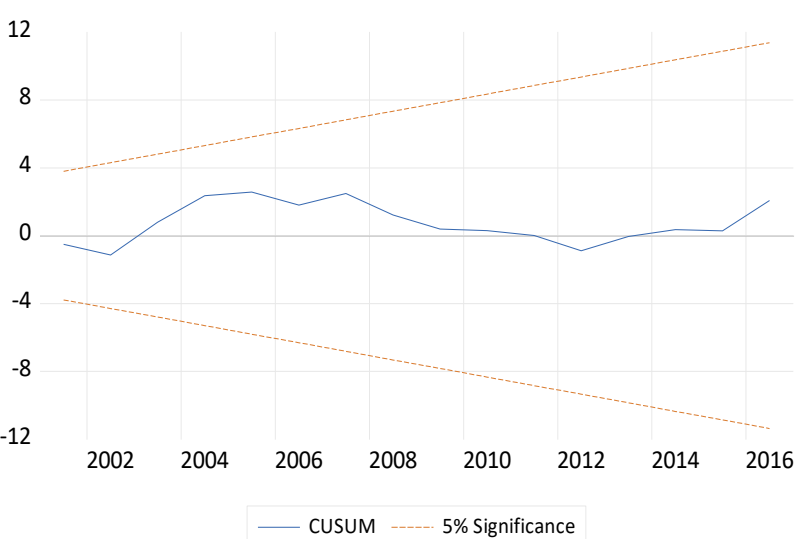

Figure 1a: Result of the CUSUM Test

\subsubsection{The Coefficients of Long-run Impacts}

To determine the impact of energy consumption on economic growth in the long run, we also employed the error correction model. Accordingly, the coefficient of LnEC variable is positive and significant at $1 \%$ level. These results implied that economic growth is affected by energy consumption in the case of Vietnam. The coefficient of DT variable is positive and significant at $1 \%$ level. This is also evidence to conclude that the impact of electricity consumption on economic growth is different between the period of 1980-1994 and the period of 1995-2016. This conclusion is also confirmed by the coefficient of (EC.DT) variable is positive and significant at $1 \%$ level. That means the contribution of electricity consumption in economic growth is lower in the period of 1995-2016. Exactly, the contribution of electricity consumption in economic growth is $0,55 \%$ over the period of $1980-1994$ and is $0,404 \%$ (= $0,554-0,150)$ in the period of 1995-2016.

Table 7: The Long-run Coefficient

\begin{tabular}{|c|c|c|c|c|}
\hline Variable & Coefficient & Std. Error & t-Statistic & Prob \\
\hline LnEC & 0.5539 & 0.0483 & 11.479 & 0.0000 \\
\hline DT & 0.3239 & 0.0986 & 3.2861 & 0.0037 \\
\hline (EC.DT) & -0.1505 & 0.0511 & -2.9466 & 0.0080 \\
\hline Intercept & 5.1928 & 0.0564 & 92.027 & 0.0000 \\
\hline
\end{tabular}

With an estimated result in Table 7, we can confirm whether short-run and long-run cointegration exists or not. But this ARDL approach does not guide us about the causal relationship among the variables. Lastly, we employed the Toda and Yamamoto (1995) procedure to test the Granger causality. The null hypothesis is $\left(\mathrm{H}_{0}\right.$ : No causal relationship) against the alternative hypothesis $\left(\mathrm{H}_{1}\right.$ : There exists a causal relationship). According to the result in Table 8, there is bidirectional causality between electricity consumption and economic growth, supported feedback hypothesis.

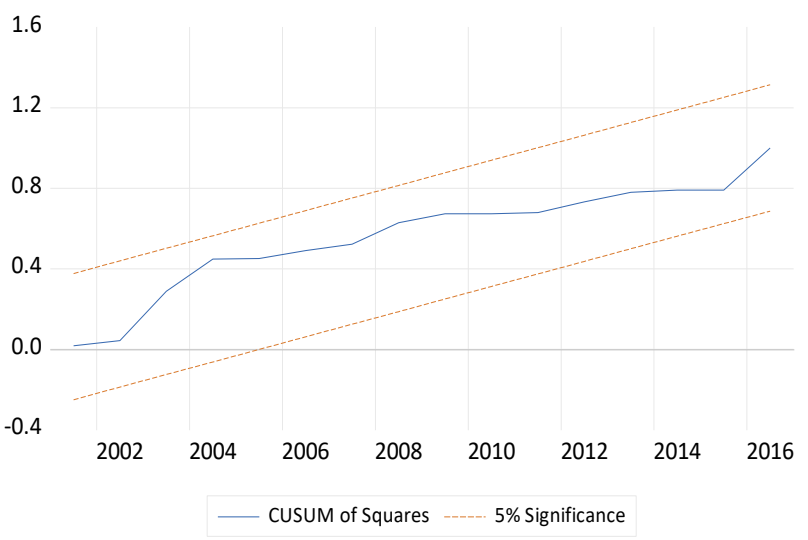

Figure 1b: Result of the CUSUMSQ Test

Table 8: Result of the Causality Test

\begin{tabular}{|l|c|c|c|}
\hline Null hypothesis: No causality & Chi_square & df & Prob \\
\hline $\begin{array}{l}\text { LnEC does not Granger cause } \\
\text { LnGDP }\end{array}$ & 9.5945 & 3 & 0.0223 \\
\hline $\begin{array}{l}\text { LnGDP does not Granger cause } \\
\text { LnEC }\end{array}$ & 13.998 & 3 & 0.0029 \\
\hline
\end{tabular}

In recent years, Vietnam's economic strategy is to diversify and deepen into the world economy. This strategy helps Vietnam attract more foreign direct investment capital, support for domestic economic growth, while also creating enormous pressure to provide adequate and timely power output for economic activities. The investment in the construction of national power lines is absolutely right. According to the author, the contribution of electricity consumption in economic growth is lower over the period of 1995-2016 is suitable. Because the advancement of high technology helps the production process and smart electricity equipment will consume less electricity.

\section{Conclusion and Policy Implications}

The main goal of this study is to investigate the impact of energy consumption on economic growth in the case of Vietnam. With the data collected from 1980-2016, we employed the ARDL approach proposed by Pesaran et al. (2001) for short-run and long-run cointegration dynamics. We also applied some diagnostic test, CUSUM and CUSUMSQ test show that our model is stable and suitable for policymaking. Lastly, to check the causal relationship among the variables, we applied the Toda and Yamamoto (1995) procedure. The empirical result of this study affirms the three following main findings:

(i) There is statistical evidence to conclude that energy consumption has a positive impact on economic growth in the long run.

(ii) There is bi-directional causality between energy consumption and economic growth, supported feedback 
hypothesis.

(iii) There is a different contribution to energy consumption in economic growth. The contribution of energy consumption in economic growth is lower over the period of 1995-2016, compared to the period of 1980-2014.

Based on the empirical results, the authors suggest some consideration when applying these results in practice, as follows:

Firstly: The national energy development strategy should be completed quickly. The energy development strategy should include a calculated rate of energy increase corresponding to the economic growth rate. A deficiency in energy will result in a decrease in economic growth, negatively impacting economic activities.

Secondly, besides exploring new energy, such as solar, wind, biofuels and geothermal power, etc., it is also essential to pay attention to raising the energy-saving sense of people/organizations. Switching to low energy consumption equipment, intelligent equipment (automatic shutdown/opening) are also ways to enhance the energy output for Vietnam.

\section{References}

Abosedra, S., \& Baghestani, H. (1989). New evidence on the causal relationship between United States energy consumption and gross national product. Journal of Energy and Development, 14, 285-292.

Abosedra, S., Dah, A., \& Ghosh, S. (2009). Electricity consumption and economic growth, the case of Lebanon. Applied Energy, 86(4), 429-432.

Akadiri, S., Bekun, F. V., \& Asumadu-Sarkodie, S. (2019). Contemporaneous interaction between energy consumption, economic growth and environmental sustainability in South Africa: What drives what? Science of the Total Environment, 686, 468-475.

Akarca, A. T., \& Long, T. V. (1980). On the relationship between energy and GNP: A reexamination. Journal of Energy and Development, 5, 326-331.

Alam, M. J., Begum, I. A., Buysse, J., \& VanHuylenbroeck, G. (2012). Energy consumption, carbon emissions and economic growth nexus in Bangladesh: Cointegration and dynamic causality analysis. Energy Policy, 45, 217225.

Ang, J. B. (2008). Economic development, pollutant emissions and energy consumption in Malaysia. Journal of Policy Modelling, 30, 271-278.

Apergis, N., \& Payne, J. E. (2009). Energy consumption and economic growth in Central America: Evidence from a panel cointegration and error correction model. Energy Economics, 31(2), 211-216.

Apergis, N., \& Payne, J. E. (2010). Energy consumption and growth in South America: Evidence from a panel error correction model. Energy Economics, 32(6), 1421-1426.

Aqeel, A., \& Butt, M. S. (2001). The relationship between energy consumption and economic growth in Pakistan.
Asia Pacific Development Journal, 8, 101-110.

Bartleet, M., \& Gounder, R. (2010). Energy consumption and economic growth in New Zealand: Results of trivariate and multivariate models. Energy Policy, 38(7), 3508-3517.

Belloumi, M. (2009). Energy consumption and GDP in Tunisia: Cointegration and causality analysis. Energy Policy, 37(7), 2745-2753.

Binh, P. T. (2011). Energy consumption and economic growth in Vietnam: Threshold cointegration and causality analysis. International Journal of Energy Economics and Policy, 1(1), 1-17.

Chang, C. C. (2010). A multivariate causality test of carbon dioxide emissions, energy consumption and economic growth in China. Applied Energy, 87, 3533-3537.

Cheng, B. S. (1998). Energy consumption, employment and causality in Japan: A multivariate approach. Indian Economic Review, 33, 19-29.

Cheng, B. S. (1999). Causality between energy consumption and economic growth in India: An application of cointegration and error-correction modeling. Indian Economic Review, 34, 39-49.

Cheng, B. S., \& Lai, T. W. (1997). An investigation of cointegration and causality between energy consumption and economic activity in Taiwan. Energy Economics, 19(4), 435-444.

Dagher, L., \& Yacoubian, T. (2012). The causal relationship between energy consumption and economic growth in Lebanon. Energy Policy, 50, 795-801.

Davoud, M., Behrouz, S. A., Farshid, P., \& Somayeh, J. (2013). Oil products consumption, electricity consumption-economic growth nexus in the economy of Iran: A bounds test co-integration approach. International Journal of Academic Research in Business and Social Sciences, 3(1), 353-367.

Dickey, D. A., \& Fuller, W. A. (1981). Likelihood ratio statistics for autoregressive time series with a unit root. Econometrica, 49, 1057-1072.

Engle, R. F., \& Granger, C. W. J. (1987). Co-integration and error correction: Representation, estimation and testing. Econometrica, 55, 251-276.

Fatai, K., Oxley, L., \& Scrimgeour, F. G. (2004). Modelling the causal relationship between energy consumption and GDP in New Zealand, Australia, India, Indonesia, the Philippines and Thailand. Mathematics and Computers in Simulation, 64(3-4), 431-445.

Ghali, K. H., \& El-Sakka, M. I. T. (2004). Energy use and output growth in Canada: A multivariate cointegration analysis. Energy Economics, 26, 225-238.

Glasure, Y. U., \& Lee, A. R. (1997). Cointegration errorcorrection, and the relationship between GDP and energy: The case of South Korea and Singapore. Resource Energy Economics, 20, 17-25.

Granger, C. W. J. (1969). Investigating causal relations by econometric models and cross-spectral methods. Econometrica, 37(3), 424-438.

Gregory, A. W., \& Hansen, B. E. (1996). Tests for 
cointegration in models with regime and trend shifts. Oxford Bulletin of Economics and Statistics, 58(3), 555560.

Halicioglu, F. (2007). Residential electricity demand dynamics in Turkey. Energy Economics, 29(2), 199-210.

Halicioglu, F. (2009). An econometric study of $\mathrm{CO}_{2}$ emissions, energy consumption, income and foreign trade in Turkey. Energy Policy, 37, 1156-1164.

Ho, C. Y., \& Siu, K. W. (2007). A dynamic equilibrium of electricity consumption and GDP in Hong Kong: An empirical investigation. Energy Policy, 35(4), 25072513.

Hwang, D., \& Gum, B. (1991). The causal relationship between energy and GNP: The case of Taiwan. Journal of Energy and Development, 16, 219-226.

IEA (2018). International Energy Agency. Available at: http://www.iea.org/statistics/

Johansen, S. (1996). Likelihood based inference in cointegrated vector autoregressive models. Oxford, UK: Oxford University Press.

Johansen, S., \& Juselius, K. (1990). Maximum likelihood estimation and inference on cointegration: With applications to the demand for money. Oxford Bulletin of Economics and Statistics, 2, 169-210.

Kraft, J., \& Kraft, A. (1978), On the relationship between energy and GNP, Journal of Energy and Development, 3(2), 401-403.

Lee, C. C., \& Chang, C. P. (2005). Structural breaks, energy consumption, and economic growth revisited: Evidence from Taiwan. Energy Economics, 27(6), 857-872.

Lee, C. C., \& Chang, C. P. (2007). The impact of energy consumption on economic growth: Evidence from linear and nonlinear models in Taiwan. Energy, 32, 2282-2294.

Lise, W., \& van Montfort, K. (2007). Energy consumption and GDP in Turkey: Is there a co-integration relationship? Energy Economics, 29(6), 1166-1178.

Long, P. D., Ngoc, B. H., \& My, D. T. H. (2018). The relationship between foreign direct investment, electricity consumption and economic growth in Vietnam. International Journal of Energy Economics and Policy, 8(3), 267-274.

Mavrotas, G., \& Kelly, G. (2001). Old wine in new bottles: Testing causality between savings and growth. Manchester School, 69(1), 97-105.

Narayan, P. K. (2005). The saving and investment nexus for China: Evidence from cointegration tests. Applied Economics, 37, 1979-1990.

Nguyen, M. H., Ngoc, B. H., Duc, V. H., \& McAleer, M. (2019). Energy consumption and economic growth: Evidence from Vietnam. Journal of Reviews on Global Economics, 8, 350-361.

Nkoro, E., \& Uko, A. K. (2016). Autoregressive Distributed Lag (ARDL) cointegration technique: Application and interpretation. Journal of Statistical and Econometric Methods, 5(4), 63-91.

Odhiambo, N. M. (2009). Energy consumption and economic growth nexus in Tanzania: An ARDL bounds testing approach. Energy Policy, 37(2), 617-622.

Oh, W., \& Lee, K. (2004). Causal relationship between energy consumption and GDP revisited: The case of Korea 1970-1999. Energy Economics, 26(1), 51-59.

Paul, S., \& Bhattacharya, R. N. (2004). Causality between energy consumption and economic growth in India: A note on conflicting results. Energy Economics, 26, 97783.

Payne, J. E. (2009). On the dynamics of energy consumption and output in the US. Applied Energy, 86(4), 575-577.

Pesaran, M. H., Shin, Y., \& Smith, R. J. (2001). Bounds testing approaches to the analysis of level relationships. Journal of Applied Econometrics, 16(3), 289-326.

Phillips, P. C. B., \& Perron, P. (1988). Testing for a unit root in time series regression. Biomètrika, 75(2), 335-346.

Rahman, S., Chen, S., Saleem, N., \& Bari, M. W. (2019). Financial development and its moderating role in environmental Kuznets curve: Evidence from Pakistan. Environmental Science and Pollution Research, 26(19), 19305-19319.

Rambaldi, A. N., \& Doran, H. E. (1996). Testing for granger non-causality in cointegrated systems made easy, Working Papers in Econometrics and Applied Statistics. No.88. England: Department of Econometrics, the University of New England.

Soytas, U., \& Sari, R. (2009). Energy consumption, economic growth, and carbon emissions: Challenges faced by an EU candidate member. Ecological Economics, 68(6), 1667-1675.

Stern, D. I. (1993). Energy and economic growth in the USA. Energy Economics, 15(2), 137-150.

Tang, C. F. (2009). Electricity consumption, income, foreign direct investment, and population in Malaysia: New evidence from multivariate framework analysis. Journal of Economic Studies, 36(4), 371-382.

Tang, C. F., Tan, B. W., \& Ozturk, I. (2015). Energy consumption and economic growth in Vietnam. Renewable and Sustainable Energy Reviews, 54, 15061514.

Toda, H. Y., \& Yamamoto, T. (1995). Statistical inference in vector autoregressive with possibly integrated processes. Journal of Econometrics, 66(1), 225-250.

Tsani, S. Z. (2010). Energy consumption and economic growth: A causality analysis for Greece. Energy Economics, 32, 582-590.

UNCTAD (2018). United Nations Conference on Trade and Development. Available at: http://unctadstat.unctad.org/wds/TableViewer/tableView. aspx? ReportId=96740,

Yu, E. S. H., \& Hwang, B. K. (1984). The relationship between energy and GNP. Further results. Energy Economics, 6(3), 186-190.

Zamani, M. (2007). Energy consumption and economic activities in Iran. Energy Economics, 29(6), 1135-1140.

Zhang, X. P., \& Cheng, X. M. (2009). Energy consumption, carbon emissions, and economic growth in China. Ecology Economics, 68, 2706-2712. 
Ziramba, E. (2009). Disaggregate energy consumption and industrial production in South Africa. Energy Policy, 37, 2214-2220.

Zivot, E., \& Andrews, D. W. K. (2002). Further evidence on the great crash, the oil-price shock, and the unit-root hypothesis. Journal of Business and Economic Statistics, $20,25-44$. 